\title{
Abstracts of Papers Presented at the Annual Meeting
}

\author{
SESSION 1A: RACIAL INEQUALITY AND ECONOMIC PROGRESS
}

Sources of African-American Economic Progress in the Labor Market in the Twentieth
Century

This paper presents a detailed accounting of the sources of African-American economic progress in the labor market over the twentieth century. We examine the received literature and demonstrate the sensitivity of conclusions stated in it to choices of samples used to measure wages and to specifications of earnings functions. We present a quantitative assessment of the contributions of migration, schooling choices, schooling quality, and social activism to both absolute levels and relative levels of African-American earnings.

JAMES HECKMAN, University of Chicago, AND PETRA TODD, University of Pennsylvania

Race and Home Ownership: A Century's View

This paper uses census IPUMS data to analyze trends in racial differences in home ownership and housing values and to examine the connection between residential segregation and the housing status of blacks relative to whites. A widening in the ownership gap between 1940 and 1960 is explained largely by the increasing concentration of blacks in central city areas but a narrowing in the ownership gap between 1960 and 1980 is explained only partly by changes in the relative characteristics of the black and white populations. Residential segregation did not widen the racial gap in home ownership rates in 1940 or 1980 , but it did tend to widen the gap in housing values after 1940. Nonetheless, there has been substantial convergence in the relative value of black and white housing since 1940 .

WILlIAM COLLINS AND ROBERT MARGO, Vanderbilt University

\section{SESSION 1B: INSTITUTIONS AND ECONOMIC GROWTH}

\section{The Colonial Origins of Comparative Development: An Empirical Investigation}

Differences in institutions are thought to be a key part of the explanation for large crosscountry differences in per capita income. Unfortunately, recent empirical research suffers from severe endogeneity problems. In this paper we provide both a theory of why different countries have different institutions and a way of measuring this, which does not suffer from endogeneity. We focus on economies that were colonized by European countries between the sixteenth and nineteenth centuries. Institutions in these countries were shaped by their colonization experience and we can use the differences in these experiences as an exogenous source of variation in institutions. We focus on differences in state institutions that depended crucially on settlement patterns. We use data on the mortality of settlers during the eighteenth and nineteenth centuries as an instrument for current institutional differences and show that institutions are a major determinant of different income levels. In our basic empirical model, once we instrument for institutions, two-thirds of the variation in current per capita income is explained by them.

DARON ACEMOGLU AND SimON JOHNSON, Massachusetts Institute of Technology, AND JAMES ROBINSON, University of California, Berkeley 
This paper examines the following puzzle: the theoretical literature written by political scientists predicts that political instability should have strongly negative impact on growth, while the empirical literature written by economists cannot detect the predicted causal relationship. We address this puzzle by first presenting a theory of how credible commitments are possible under conditions of political instability and then by operationalizing this theory using quantitative evidence from Mexico during the period 1900-1934. The evidence is drawn from both archival and published sources.

STEPHEN HABER AND ARMANDo RAZO, Stanford University, AND NOEL MAURER, ITAM

World Capitalist Growth Patterns: The Myth that Neoclassical Growth Models Apply Worldwide

An increasing number of cross-national studies of macroeconomic growth that pool data on developed and underdeveloped countries seek to explain world growth patterns with a single model and propose universal policy prescriptions for market reform. This paper questions the applicability to most underdeveloped countries of this literature's generalizations about growth, convergence, living standards, and economic policy. I use little known Adelman and Morris historical cross-country estimates for the late nineteenth and midtwentieth centuries to demonstrate that the consequences of capitalist market expansion typically vary so greatly across different development levels, different development paths, and different institutional settings that no single set of theory-based policy prescriptions in applicable.

Cynthia TAFT MORRIS, Smith College

\section{SESSION 2A: VALUES AND ECONOMIC GROWTH}

\section{The Middle-Class Consensus and Economic Development}

Modern political economy stresses "society's polarization" as a determinant of development outcomes. Among the most common forms of social conflict are class polarization and ethnic polarization. The paper links the existence of class polarization to exogenous country characteristics such as resource endowments, along the lines of the provocative economic-history thesis of Engerman and Sokoloff that tropical commodity exporters are more unequal than other societies. This hypothesis is confirmed with cross-country data. This makes it possible to use resource endowments as instruments for inequality. A higher share of income for the middle class and lower ethnic polarization are empirically associated with higher income, higher growth, more education, better health, better infrastructure, better economic policies, less political instability, less civil war and ethnic minorities at risk, more social "modernization" and more democracy.

WILLIAM EASTERLY, World Bank 
America's Differential Impact on World Culture

The twentieth century saw the rise of the United States to world economic and political supremacy. This rise, together with advances in communications and transportation technology and the great expansion of international economic and political relations with the United States at its center, has placed America in a position of unparalleled influence in the evolution of world culture. Country after country throughout the world is falling in line, replicating the American model of material lifestyles, so far as they are able. In contrast, political democracy, one of America's proudest and most proclaimed achievements, has only a limited reception worldwide. Indeed, since 1950 in the less developed world there has been little or no advance in political democracy. This paper will sketch quantitatively the twentieth-century rise of the United States to world supremacy and the differential economic and political impact of the Unites States on world culture. It will also speculate on the reasons for the uneven cultural effects and consider implications of the analysis for the future of world culture.

RICHARD EASTERLIN, University of Southern California Property Rights, Political Rights, and the Development of Poor Countries in the Post-
Colonial Period

Two distinctive institutional features of the United States are well-defined property rights and broad-based political rights. Cross-sectionally and longitudinally, the two institutions tend to go together, but not all that closely. There are countries with reasonably good property rights and little democracy (Korea, Taiwan, Chile, China, Uganda), and ones with democracy but weak rule of law (Russia, Ukraine, Yemen, Honduras, Jamaica). We find that strength of property rights has a clear relationship to growth. However, there is no relationship between extent of democracy and per capita growth. Focusing only on the income of the bottom 20 percent of the population, we find the same relationships. These findings shed light on the role of foreign savings in promoting development. Private capital tends to flow to where the rule of law is strong-without reference to democracy-and those flows accelerate the development of such areas. On the other hand, foreign aid has tended to favor democracies-without regard to the rule of law or economic policies. Because most foreign aid has been disbursed into environments with weak rule of law and poor economic policies, it has had relatively little impact on the development of poor countries.

DAVID DOLLAR AND ART KRAAY, World Bank

\section{SESSION 2B: WARS AND STRUCTURE OF GOVERNMENT}

Wars and the Evolution of Fiscal Regimes in Europe, 1700-2000

Fiscal regimes have become progressively more centralized and though the trend extends over nearly a millennium, the process accelerated in the early nineteenth century. The growth of central government budgets as a fraction of the economy and relative to local and regional budgets is well known. Many believe that the process has been driven by changes in citizens' demand for social services and therefore have associated it with democratization and with crises such as World War I and the Great Depression. In this paper we take 
a different tack and consider the evolution of fiscal institutions and changes in the preferences of the central executive. Our reconsideration is prompted by the observation that from and institutional standpoint fiscal centralization long preceded the massive expansion of the welfare state in the twentieth century.

Philip Hoffman, California Institute of Technology, AND JEAN-LAURENT ROSENTHAL, University of California, Los Angeles

Filling the Void? Implications of the Lack of American Military Leadership on the Military Spending of European Democracies, 1920-1938

This article explores the phenomenon of military spending in eight Western democracies (United Kingdom, France, United States, Belgium, Denmark, Finland, Norway, and Sweden) during the interwar period, especially focusing on the last of American military leadership. The hegemonic perspective advocated by many suggests that the economic leader of a system has to dedicate growing resources to security, eventually harmful to economic growth. The military spending patterns here suggest that, similar to totalitarian nations, the United Kingdom and France challenged the limited American leadership in the 1920s and 1930s. Regression analysis supports this conclusion. However the military spending levels were too low to warrant making conclusions about the respective economic impacts. This result is also verified here by employing Granger noncausality tests between military spending and economic growth variables for these nations.

JARI ELORANTA, European University Institute

\section{The Size of the U.S. Armed Forces During World War II}

The size of the American armed forces in World War II resulted from early decisions which reflected both the nature of the threat and the degree of American popular commitment. A key decision follow the feasibility dispute of 1942. In this dispute, the immense demands of the President, the War Department, and the Navy Department in early 1942 were challenged by the GNP and labor-force analysis of Simon Kuznets and Robert Nathan of the War Production Board. Based on an examination of War Production Board documents, this paper shows how Kuznets and Nathan used the infant theory and practice of GNP accounting to frame the case for the infeasibility of these first war plans. Kuznets and Nathan not only had an immediate impact on war spending in late 1942 and 1943 but he standard of living constraint they identified remained a crucial element in the economic shape of America's entire war effort.

Michael EdELSTEIN, Queen's College, CUNY

\section{SESSION 3: PLENARY GEOGRAPHY AND ECONOMIC DEVELOPMENT OVER THE LONG RUN}

Why Did Human History Unfold Differently on Different Continents for the Last 13,000 Years?

History's broadest pattern, and its biggest unsolved problem, are its very different course on different continents. Why did Aboriginal Australians remain stone-age hunter-gatherers, 
while agriculture and empires were arising among Native Americans, and while widespread literacy and metal tools were arising in Eurasia? Why were Europeans the ones to conquer Africans, Aboriginal Australians, and Native Americans, instead of vice versa? For lack of an accepted explanation, many people fall back on racist explanations. I shall show instead how the different fates of different peoples were stamped by differences in continental environments.

JARED DIAMOND, University of California, Los Angeles

Why are the Tropics Poor? Assessing the Roles of Politics, Economics, and Ecology

Most recent cross-country analyses of economic growth have neglected physical geography as a determinant of economic growth. This paper reviews the distinctive development challenges faced by economies situated in tropical climates. Using geographic information system (GIS) mapping, the paper presents evidence that production technology in the tropics has lagged behind temperate zone technology in the two critical areas of agriculture and health, and this in turn opened a substantial income gap between climate zones. The difficulty of mobilizing energy resources in tropical economies is emphasized as another significant contributor to the income gap. These factors have been amplified by geopolitical power imbalances and by the difficulty of applying temperate-zone technological advances in the tropical setting. The income gap has also been amplified because poor public health and weak agricultural technology in the tropics have combined to slow the demographic transition from high fertility and mortality rates to low fertility and mortality rates. The analysis suggests that economic development in tropical ecozones would benefit from a concerted international effort to develop health and agricultural technologies specific to the needs of the tropical economies.

JEFFREY SACHS, Harvard University

\section{SESSION 4A: ECONOMIC WARFARE}

Legal and Economic Aspects of Naval Blockade: The United States, Great Britain, and German in World War II

This paper examines various legal, economic, and technological aspects of economic warfare - particularly naval blockades. It begins with a summary of the rules of international law that most developed countries "agreed" should govern "legal" blockades, and the degree to which they are enforceable. The focus is then narrowed to a particular example of a blockade - the varying success of the German submarine blockade of the British Isles and the Eastern Coast of the United States during World War II. The basis for the early German success is described, as are the contribution of the varying technological (radar, Huff-Duff, the hunter-killer groups) and organizational (convoys and command) innovations in the subsequent allied success. The role of the link between the scientific and military community and the increased ability of the Americans to produce shipping are also discussed as factors essential to successfully ending the submarine blockade. Finally, the paper raised questions about the possibility of enforcing "legal rules" during a "total" war and about the role, pro and con, of individuals in structuring blockades and countermeasures.

LANCE DAVIS, California Institute of Technology, AND STANLEY ENGERMAN, University of Rochester 
A Wolfram in Sheep's Clothing: Economic Warfare in Spain and Portugal, 1939-1944

One of the most sustained uses of economic warfare by the Unites States occurred in Spain and Portugal during World War II. We provide an overview of this episode by weaving together findings from the secondary literature and from new research carried out in the Spanish archives. The war evolved through several distinct phases. (1) An oil embargo against Spain, although launched when Germany appeared to be winning (July 1940 to September 1940), was successful in helping to keep Spain neutral because it forced the Franco regime to rethink the costs of joining forces with Germany. (2) Preemptive buying of wolfram (tungsten) during the middle years of the war was also successful because it forced the Germans to pay more for and to consume less wolfram. (3) Ironically, a second oil embargo against Spain, undertaken when the Germans were retreating on all fronts (22 January 1944 to 2 May 1944) was less successful. The major goal, cutting shipments of wolfram to Germany, was not fully realized, partly because monitoring costs were high.

HUGH ROCKOFF, Rutgers University, AND LeONARD CARUANA, CEU San Pablo University

\section{SESSION 4B: THE GREAT DEPRESSION-MACRO}

\section{Understanding the Great Depression in the United States versus Canada}

The Great Depression was a global phenomenon. Therefore, a comparison of the U.S. and Canadian experiences is helpful, because of the close economic ties the two countries share and because of significant differences between the two countries' financial structures. Yet, both countries experienced the Great Depression at roughly the same time and of comparable economic magnitude. The survey finds that a single cause is not responsible for this event. Nevertheless, what is striking is that despite differences in the two countries' financial structures, both countries suffered a tremendous slump. Institutional differences are insufficient to insulate a country from foreign shocks or their role in insufficiently understood. I conclude that the "ideology" of the Gold Standard was significant in overcoming the potential for institutional differences to cushion the blow of the Great Depression in Canada.

PIERRE SIKLOS, Wilfrid Laurier University

Was the Federal Reserve Fettered? Devaluation Expectations in the 1932 Monetary Expansion

A key question about the Great Depression is whether expansionary monetary policy would have caused a speculative attack on the dollar. This paper uses the $\$ 1$ billion expansionary open-market operation undertaken in the spring of 1932 as a crucial case study of the credibility of the United States' commitment to the gold standard. Data on forward exchange rates are used to measure expectations of devaluation during this episode. We find little evidence that the large monetary expansion led investors to believe that the United States would devalue. The financial press and the records of the Federal Reserve also show little evidence that a speculative attack was developing or even feared during the open-market operations. We find that a flawed model of the effects of monetary policy and 
a power struggle among the 12 Federal Reserve banks, rather than a fear of a speculative attack, led the Federal Reserve to suspend the expansionary policy in the summer of 1932.

CHRISTINA ROMER, University of California, Berkeley, AND CHANG-TAI HsieH, Princeton University

\section{SESSION 5A: PRODUCTIVITY}

\section{Early Twentieth Century American Productivity Growth Dynamics}

A marked acceleration of total factor productivity (TFP) growth in U.S. manufacturing followed World War I. The paper analyzes this development, attributing it to the confluence of diffusion of a general-purpose-technology (electrification) with a regime change in the industrial labor market.

The proximate source was the switch from declining or stable capital productivity to a rising capital-output ratio, which occurred at this time in many branches of manufacturing, and which was not accompanied by slowed growth in labor productivity. The era also witnessed profound transformations in the labor market, following the stoppage of mass immigration from Europe. Rising real wages provided strong impetus to changes in workforce recruitment and management practices that had been underway in some branches of industry before the war. Complementarity between these two forces is indicated by a marked positive correlation between changes in capital productivity and labor productivity during the 1920 s.

PAUL DAVID, Oxford University and Stanford University, AND GAVIN WRIGHT, Stanford University

\section{Explaining Comparative Productivity Levels in Services: Technology and Organisation in Britain, the United States, and Germany, 1870-1990}

Contrary to popular perceptions, trends in comparative productivity levels for the whole economy have been driven primarily by trends in services rather than by trends in industry. We provide a model of interactions between technology and organization that explains changing productivity leadership in services. Whereas Britain developed social capabilities geared to the operation of networks, the United States developed social capabilities geared to the operation of hierarchies. Germany was in a better position to adapt to the technological changes that favored hierarchies during much of the twentieth century, because Germany had not developed social capabilities geared to networks to the same extent as had nineteenth-century Britain. Nevertheless, these technological changes did not affect all sectors at the same pace, and Britain continued to do relatively well in sectors that remained suited to networks.

STEPHEN BROADBERRY AND SAYANTAN GHOSAL, University of Warwick

\section{SESSION 5B: THE GREAT DEPRESSION-BANKING}

\section{The Speed of Bank Liquidation and the Propagation of the U.S. Great Depression}

Bernanke suggested that the source of credit-channel effects lies in the longevity of credit disruptions. The investigate how the duration of credit-channel effects influenced macro- 
economic activity during the Great Depression, we employ the amortized stock of deposits in closed banks, which contains information about the time it takes to rehabilitate insolvent debtors or liquidate their collateral. As found by Bernanke and others, vector autoregression models provide evidence that changes in prices explained the largest proportion of fluctuations in industrial output. In our model the stock of closed national banks' deposits was as important as the money stock in terms of explaining output changes. Consistent with recent theoretical work on the financial system and economic growth, our new credit proxy provides evidence that the dynamic effects of credit disruptions were cumulative and pervasive during the Depression.

JOSEPH MASON, Drexel University, AND ALI ANARI AND JAMES KOLAN, Texas A\&M University

Internal versus External Convertibility and Developing Country Financial Crises: Lessons from the Argentine Bailouts of the 1930s

Argentina's money and banking system was hit hard by the Great Depression. Banks were awash with bad assets when gold convertibility was suspended in December 1929. We argue for an explanation of the crisis that focuses on the inside-outside money relationship in a system of fractional-reserve banking and gold-standard rules with a tension between internal and external convertibility. After financial fragility appeared in the 1914-1927 suspension, resumption in 1928 was probably unsustainable due to the problems of the financial systems. A dynamic model illustrates the point well. When the state bank became insolvent, the currency board started bailing out the system using high-powered money. Thus came about the demise of the currency board and the creation of a central bank in 1935. As one of its first substantive actions, the central bank engineered a bailout of the banking system at a massive social cost. The parallels with recent developing-country crises are remarkable, and the implications for the institutional design of monetary and banking systems are considered.

ALAN TAYLOR, University of California, Davis, AND GERARDO DELLA PAOLERA, Universidad Torcuato de Tella

\section{SESSION 6: PLENARY}

\section{Celluloid Capitalism-Entrepreneurs in Action}

Movies might appropriately be the defining genre for the twentieth century. There were no movies before the twentieth century. Knowing what movies were made and seen by whom over time, and which messages and symbols were conveyed tells us a great deal about the American Century and about how people saw capitalists and capitalism. We argue that American movie culture evolved at a time when the debate about wealth and poverty and structural change was transforming the economy, and when most people could not explain or understand the revolutionary changes underway. We also suggest that who made the movies and how they made them mattered: a majority of the early movies were made by immigrant groups, such as Jews, and that mattered to how the movies perceived the outsiders and the insiders and how they portrayed capitalism and capitalists.

We have put together the most enjoyable and intellectually interesting pastiche possible. We use the movies to tell a story about capitalism by selecting and watching the movies 
that people watched over the course of the long twentieth century. We follow the changes in movie makers' portrayal of capitalists and capitalism, and to imagine more clearly, how these changes in the way movies portrayed capitalism help to understand the mixed messages that were conveyed to people who saw and experiences those movies over time.

Moderator: JOHN LITHGOW, actor, Participants: MARY COREY, University of California, Los Angeles, AND Ella TAYLOR, Los Angeles Weekly

\section{SESSION 7A: TECHNOLOGY AND BUSINESS HISTORY}

The Evolving Structure of Coordination: Toward a New Synthesis of American Business History

This paper is an effort to build on the essays collected in our three NBER conference volumes by offering a new synthesis of American business history. We move beyond the traditional markets versus hierarchies (or markets versus central planning) dichotomy and argue that one can observe in the cross-section of the economy at any moment in time a variety of coordination mechanisms in use, man of which do not fit neatly into these ideal types. We argue further that one can speak of the incidence of these different mechanisms in cross-section, and hence one can speak of modal mechanisms and hence of the history (that is, evolution) of these cross-sections. Finally, we argue that changes over time in the incidence of these coordination mechanisms were propelled by forces that can be taken as exogenous including, most importantly, improvements in transportation and communications, urbanization, and the general rise in per capita income.

\section{NAOMI LAMOREAUX, University of California, Los Angeles, DANIEL RAFF, University of Pennsylvania, AND PETER TEMIN, Massachusetts Institute of Technology}

\section{Copyrights, the Infringement of Intellectual Property, and American Economic Development}

American copyright statutes since 1750 protected the rights of citizens to use and exclude others from using their literary property, but until 1891 deemed the works of foreign citizens to be in the public domain. In 1891 the laws were changed to allow for foreign filings if certain conditions were met. Thus, this episode in American history provides us with a convenient way of investigating the importance of property rights in literary works and the likely implications for developing countries today that ignore international legal standards towards intellectual property. This paper employs financial data from the accounts of a major publishing company, copyright registrations, lawsuits related to copyright questions, and information on authors and titles to investigate the welfare effects of widespread infringement of foreign works. 
Government, Computing, and the American Century: What Role Antitrust?

This essay traces major interventions by the Justice Department into the data processing industry since the 1930s, analyzing their goals and effects. It suggests that government has consistently attempted to break the bonds between providers of basic technical platforms and firms oriented toward tailoring those platforms to meet the varied desires of consumers. This goal informed the watershed cases against IBM, including the consent decree of the 1950s that separated marketing of hardware from services and the action of the mid-1960s that encouraged IBM to unbundle software and hardware. Whether these actions significantly altered the course of change in the industry remains in doubt. Analysis of economic data and of business behaviors suggests the interventions either exerted limited influence or simply reinforced trends already underway due to changing technology and shifting consumer demand. More recent developments in the era of the networked personal computer echo these earlier experiences.

STEVEn UsSelman, Georgia Institute of Technology

\section{SESSION 7B: SPATIAL ORGANIZATION OF ECONOMIC ACTIVITY}

\section{The Rise and Decline of Density in Economic Activity}

In the United States the density of economic activity in cities differed significantly over time. Between the eighteenth and early nineteenth centuries, cities became increasingly dense; however, since the second half of the twentieth century, the trend has reversed as cities have become dispersed. The density of economic activities differed significantly across cities as well. At any given point in time, there is a great variation in the density of economic activities across cities. The dynamic changes in the spatial organization of economic activities also differed across cities. In some cities, such as New York, population density grew and plateaued while in others, such as St. Louis, it grew and fell dramatically. Yet, despite the fact that the defining element of a city is its density, few scholars have systematically examined the long-run changes in the spatial organization of economic activities. This paper documents the historical changes in the density of economic activities and explores the causes of their rise and decline.

SUKKOо KIM, Washington University, St. Louis

\section{America's Century and the Rise of California as a Center of Economic Activity}

A significant although relatively unexplored aspect of U.S. economic history over the twentieth century is the rise of the American West, especially of California, as a center of economic activity. This paper uses a new panel data set on manufacturing industries in California and the United States to investigate the underlying forces driving the economic rise of the region. This analysis views the long-run growth of California as a process of endogenous scale-dependent development, much like the dynamics highlighted in the New Economic Geography. It also identifies several important economy-wide shifts over the twentieth century, including changes in power sources, rising demand for human capital, the weakening of pressures for larger scale, and the increased contribution of R\&D investments in production, that facilitated the region's development.

PAUl RHODE, University of North Carolina, Chapel Hill 


\title{
SESSION 8A: INDUSTRY STUDIES AND STRUCTURES
}

\author{
The Closing of the Frontier in Barbados: Economies of Scale and the Distributional \\ Impact of the Sugar Revolution
}

This paper investigates the dynamics of rapid frontier development in the 40 years of Barbados' history before 1680, the decades of its transition to sugar island and slave-based "plantocracy" from a settler economy peopled by white servants and numerous small landowners. It uses a linked data set of several thousand individuals who appeared over time in three key data sources: the 1665 export registration, the 1679 census holdings of property, and the record of deeds. Combining these sources into career histories of thousands of the people who lived in Barbados during its sugar revolution make it possible to answer some of the most intriguing questions about that economic transition. In particular, these new data shed light on the land-consolidating activities of individual landowners over time, the role of small planters and artisans in the process of land clearing and agricultural capital formation, and the participation of merchants and foreign investors in creating sugar enterprises.

EMILY MeChNeR, Bates College

Settling Auto Disputes in Court: Efforts to Define Relationships Among Car Buyers, Dealers, and Manufacturers, 1905-1916

Between 1905 and 1916 car buyers, dealers, and manufacturers routinely went to court to clarify their authority and obligations. I argue that manufacturers tried to exert power through the courts so as to limit their obligations to franchised dealers, declaring dealers were in legal terms not their agents in a principal-agent relationship but simple independent vendors. The courts also granted dealers a measure of leeway in being truthful in selling cars through a concept known as "seller's talk." But for car buyers, the courts held manufacturers negligent to a third party for selling defective products when basic research could prevent imperiling a car's occupants. Insofar as these relationships continue to spark conflicts and complaints about autos, my essay locates a legal basis for the distrust. The lawsuits also offer one strategy for examining a question central to Henry Luce's "American Century": what sort of attitudes has economic power engendered?

SALLy Clarke, University of Texas, Austin

\section{The Puzzling Demise of the Whiskey Trust}

Between 1880 and 1900 thousands of businesses in the United States combined to form what were loosely referred to as "trusts." The trust movement ultimately gave rise to some of the largest and most famous enterprises in American history. Yet for all of the successful combinations that emerged from the trust movement, most trusts failed. Nearly all existing studies of the trusts, however, focus on the successful enterprises, and little is known about the combinations that failed. To understand why some trusts succeeded, it is necessary to better understand why so many others failed. Accordingly, this paper analyzes the rise and fall of the Whiskey Trust, which dominated the production of alcoholic spirits, from 1887 through 1895. Four possible explanations for the demise of the trust are considered: anti- 
trust regulations; managerial misconduct and mismanagement; market entry; and unanticipated shocks to supply or demand.

KAREN CLAY, Carnegie Mellon University, AND WERNER TROESKEN, University of Pittsburgh

\section{SESSION 8B: FOREIGN TRADE AND POLICY DURING THE AMERICAN CENTURY}

\section{Transformation of the Japanese Economic System: A Reappraisal of the Occupation}

Why and how did the institutional characteristics often described as the Japanese system of the Japanese enterprise system emerge? Although there is a broad consensus among researchers that Japan's enterprise system emerged between 1930 and 1955, researchers differ with regard to the importance of the prewar system, changes and their magnitude during the wartime planned economy, and the impact of postwar reforms. Okazaki suggested that the origin of the current Japanese economic system can be found in the wartime planned economy. In contrast, this paper suggests that the impact of postwar reform was crucial for establishing the current system. Specifically, that GHQ's "Americanization" of the economic system created a discontinuous transformation of that system. This paper highlights the effects of occupation reform on changes in corporate finance, governance, and industrial organization. In order to clarify the transformation process of the economic system, I use microdata for capital composition, ownership structure, and firm behavior such as depreciation and investment, which I collected from the 126 largest industrial and mining firms.

HIDEAKI MiYAJIMA, Waseda University

\section{Reducing Transaction Risk in Trade Between Japan and the United States: The Role of General Trading Companies, 1915-1941}

In 1853 when Commodore Perry used military force to end Japan's 250 year isolation from the rest of the world, Japan's economy was abruptly exposed to foreign trade. Neither Japan nor the United States had much information or experience about the customs, language, legal traditions, or markets of the other, which increased the risks of making and enforcing international contracts. General trading companies arose to reduce such risks, and were particularly important in Japan where these risks existed for every foreign transaction. Archived records of the U.S. branches of two Japanese trading companies demonstrate that these companies absorbed risk associated with international trade for both U.S. and Japanese clients. The documents also support the claim that trading companies were able to mitigate transaction risks on their own behalf enough to maintain a profitable business as an intermediary. Thus, general trading companies expanded the amount of trade possible between Japan and the United States.

JENNIFER FRANKL, Williams College

\section{Governing Foreign Trade: The Effects of Sugar Legislation on U.S.-Cuban Relations}

Our paper adopts the method of the event study to examine the effect of legislative revisions to the U.S. Sugar Program between 1945 and 1959 on its principal suppliers. The 
institutional design of the sugar import quota system made its governance vulnerable to rent seeking by domestic producers. We examine the response of stock prices of sugar companies representing major supplier groups, each of which faced different consequences from modifications to the regulatory environment. Mainland producers, domestic refiners, U.S. insular possessions, and Cuba represent the major supplier groups. Estimation of abnormal rates of return to shareholders captures the responses of investors to changes in the relative earnings potential of companies, and comparison across supplier groups tests our hypothesis that the relative effects of sugar-policy revisions were destabilizing to the Cuban economy and polity. The findings may suggest profound influence of the institutional design of regulatory policy on determining the long-run winners and losers of a policy.

ALAN Dye, Barnard College, AND RICHARD SICOTTE, University of Calgary 